\title{
USULAN PENGENDALIAN KEBUTUHAN PERSEDIAAN MENGGUNAKAN METODE ECONOMIC ORDER QUANTITY DI PT. INDOTRUCK UTAMA CABANG JAKARTA
}

\author{
Meri Prasetyawati, Umi Marfuah, Gofan Wijaya \\ Jurusan Teknik Industri, Fakultas Teknik \\ Universitas Muhammadiyah Jakarta, Jakarta Pusat \\ merie_jeng@yahoo.co.id
}

\begin{abstract}
Abstrak
PT. Indotruck Utama Cabang Jakarta adalah sebuah perusahaan yang bergerak sebagai penyalur penjualan genuine spare part dan alat-alat berat (heavy equipment) berbagai jenis merek, juga tidak lepas dari masalah persediaan. Persoalan yang terkait dengan fenomena kinerja sistem persediaan terutama part oil filter yang seharusnya dilakukan proses order dengan mode pengiriman sea freight akan tetapi secara aktualnya sering terjadi proses order dengan mode pengiriman Air freight dimana tentunya biaya pengiriman atau pengadaan suku cadang menjadi lebih besar akibat dari stock out. Adanya pemborosan dalam biaya pengiriman dengan mode pengiriman air freight \$23,199.00 dimana seharusnya biaya ini tidak akan muncul apabila stock suku cadang yang ada bisa cukup memenuhi permintaan dan pengiriman dengan menggunakan mode pengiriman sea freight yang pastinya lebih ekonomis.Evaluasi sistem persediaan dilakukan terhadap kinerja sistem persediaan saat ini yang kemudian dilakukan analisis untuk meningkatkan kinerja sistem persediaan melalui penentuan kebijakan persediaan yang optimal. Dengan melakukan Forecasting (peramalan) untuk kebutuhan suku cadang untuk 1 tahun kedepan dan menghitung hasil peramalan tersebut dengan menggunakan metode economic order quantity (EOQ).Hasil evaluasi untuk memenuhi permintaan akan kebutuhan suku cadang oil filter ini diusulkan dengan total biaya sebesar \$ 54.188. Metode EOQ ini bisa menjadi pilihan perusahaan sebagai metode untuk melakukan proses order dimana ada selisih sebesar $\$ 10.612$ atau penghematan dari rencana pembelian perusahaan dan diharapkan mampu memenuhi permintaan suku cadang dengan biaya pengadaan yang ekonomis.
\end{abstract}

Kata Kunci: Inventory, Forecasting, Economic Order Quantity (EOQ)

\section{PENDAHULUAN}

PT. Indotruck utama adalah Agen Tunggal Pemegang Merek (ATPM) dari salah satu anak perusahaan Indomobil yang bergerak dalam bidang kendaraan alat berat merek Volvo Truck, Volvo Construction Equipment, Renault Truck, Kalmar, Manitou, dan SDLG yang merupakan salah satu distributor otomotif terbesar dan produsen di indonesia.Sebagai perusahaan yang bergerak dalam bidang supply suku cadang untuk alat berat, maka ketepatan dalam melayani konsumen merupakan hal yang sangat penting. Konsumen tidak bisa dibiarkan menunggu terlalu lama untuk mendapatkan komponen yang dibutuhkannya.Salah satu kendala yang dihadapi adalah masalah geografis. Sebagian besar pemakai alat berat Volvo berada di daerah terpencil seperti di dalam pertambangan di Kalimantan, ditengah perkebunan sawit di Sumatra ataupun hutan tanaman industri karena alat berat tersebut utamanya digunakan untuk operasi pertambangan, perkayuan, perkebunan, dan konstruksi.Dari data yang diperoleh ada 3 item teratas yaitu oil filter 21707134, 21707133, dan 21707132 yang akan dilakukan penelitian karena item tersebut yang selama ini selalu mengalami kekurangan stock yang seharusnya dilakukan order mode pengiriman sea freight tetapi pada aktualnya sering terjadi kekurangan yang akhirnya di order dengan mode pengiriman Air freight yang tentu saja banyak memakan biaya pengiriman yang cukup tinggi. adanya pemborosan sebesar $\$ 23,199.00$ akibat dari pengiriman via udara yang seharusnya tidak terjadi. Oleh karena permasalahan diatas maka peneliti akan melakukan perhitungan forecasting atau peramalan dan kemudian menghitung hasil peramalan tersebut dengan metode Economic Order Quantity (EOQ), 


\section{STUDI PUSTAKA}

A. Metode Peramalan

Peramalan adalah suatu perkiraan tingkat permintaan yang diharapkan untuk suatu produk atau beberapa produk dalam periode waktu tertentu dimasa yang akan datang. Dengan menggunakan data permintaan pada periode sebelumnya yang akan menjadi dasar peramalan yang diperlukan oleh setiap perusahaan untuk merencanakan jumlah produksi yang akan datang, peramalan juga mempunyai peranan langsung terhadap pengambilan keputusan.Peramalan merupakan tahap awal dari perencanaan dan pengandalian produksi. Peramalan adalah pemikiran terhadap suatu besaran, misalnya permintaan terhadap suatu atau beberapa produk pada periode yang akan datang. Pada hakekatnya peramalan merupakan suatu perkiraan terhadap keadaan yang akan terjadi di masa yang akan datang. Keadaan masa yang akan datang yang dimaksud adalah apa yang dibutuhkan (jenis), berapa yang dibutuhkan (jumlah/kuantitas), kapan dibutuhkan (waktu).

\section{B. Aplikasi Peramalan Permintaan Dengan Menggunakan Software WinQSB}

WinQSB adalah salah satu software yang juga dapat kita manfaatkan untuk melakukan perhitungan peramalan permintaan didalam perencanaan dan pengendalian produksi. Tersedia 11 algoritma untuk melakukan peramalan permintaan dengan model peramalan time series, yaitu peramalan dengan menggunakan deret waktu.

Metode Peramalan Time Series yang tersedia pada software tersebut adalah:

1. Perataan Sederhana (Simple Average)

2. Perataan Bergerak (Moving Average)

3. Perataan Bergerak Yang Dibobotkan (Weighted Moving Average)

4. Perataan Bergerak Dengan Trend Linier (Moving Average With Linear Trend)

5. Pemulusan Eksponensial Tunggal (Singel Eksponensial Smoothing)

6. Pemulusan Eksponensial Tunggal Dengan Trend Linear (Singel Eksponensial Smoothing With Linear Trend)

7. Pemulusan Eksponensial Berganda (Double Eksponensial Smoothing)

8. Pemulusan Eksponensial Berganda Dengan Trend Linear (Double Eksponensial Smoothing With Linear Trend)

9. Regresi Linier (Linear Regression)

10. Algoritma Winter Dengan Additive dari Holt (Holt-Winters Additive Algorithm)

11. Algoritma Winter Dengan Multiplicative dari Holt (Holt-Winters Multiplicative Algorithm)

Terdapat beberapa kriteria performansi untuk membandingkan model-model peramalan time series yang kita gunakan dengan memanfaatkan WinQSB, antara lain : Mean Absolute Deviation (MAD), Mean Square Error (MSE), Cumulative Forecast Error (CFE), Mean Absolute Percent Error (MAPE).Disamping itu software ini juga memiliki fungsi untuk melakukan verifikasi peramalan dengan menyediakan fungsi perhitungan Tracking Signal.

\section{Proses Perhitungan Peramalan Dan Output Data}

1. Gunakan perintah Perform Forecasting dari menu Solve and Analyze atau klik icon dari tool bar. WinQSB juga memiliki fasilitas Help apabila ada penjelasan yang dibutuhkan.

2. Setelah tampil display Forecasting Setup, lakukan input selanjutnya dengan :

- Klik Forecasting Method, misalkan Singel Exponensial Smoothing (SES)

- Klik Method Parameters, misalkan Assign Value

- Klik Search Criterion. Misalkan MAD

- Isilah Number of periods to forecast, misalkan 12

- Isilah Smoothing exponential alpha, misalkan 0,5 
- Kllik button OK apabila input telah selesai dilakukan

3. Apabila kita juga ingin menggunakan metode peramalan yang lain (misalnya metode Double Exponential Smoothing/ DES) dan membandingkan hasilnya dengan metode sebelumnya, kita gunakan perintah Perform Forecasting kembali, dan lakukan input data kembali untuk kelengkapan data DES tsb, kemudian kita pilih Retain Other Method's Result dan klik button OK

4. Kita dapat melihat perbandingan output dalam bentuk grafik dengan menggunakan perintah Show Forecasting in Graph dari menu Result

5. WinQSB juga menyediakan fungsi penelusuran parameter terbaik berdasarkan metode yang digunakan. Misalkan kita ingin mendapatkan parameter terbaik dengan menggunakan algoritma Winter Additive dari Holt dengan kriteria performansi MAD : Gunakan perintah Perform Forecasting dari menu Solve and Analysis, setelah memilihMAD dan seasonal cycel $=12$ bulan, klik button Enter Search Domain, lalu OK.Untuk tampilan berupa grafik gunakan perintah Show Forecasting in Graph dari menu Result.

6. Untuk mengetahui hasil perhitungan detil perhitungan peramalan yang dilakukan, perintah Show Forecasting Detail dari menu Result.

\section{Metode Economic Order Quantity (EOQ)}

Model EOQ bisa digunakan untuk menentukan kuantitas pesanan persediaan yang meminimumkan biaya langsung penyimpanan persediaan dan biaya kebalikannya (Inverse cost) pemesanan persediaan.Pendekatan menggunakan teknik ini dilakukan atas dasar minimasi ongkos simpan dan ongkos pesan.Ukuran lot tetap berdasarkan hitungan minimasi tersebut. Teknik EOQ tidak hanya digunakan pada perhitungan MRP saja, penerapannya sudah berkembang pada system persediaan tradisional, hal ini didasarkan dengan adanya asumsi bahwa kebutuhan bersifat continue terhadap pola permintaan yang stabil.

ASUMSI EOQ :

1. Kecepatan permintaan tetap dan terus menerus.

2. Waktu antara pemesanan sampai dengan pesanan dating (lead time) harus tetap.

3. Tidak pernah ada kejadian persediaan habis atau stock out.

4. Material dipesan dalam paket atau lot dan pesanan dating pada waktu yang bersamaan dan tetap dalam bentuk paket.

5. Harga per unit tetap dan tidak ada pengurangan harga walaupun pembelian dalam jumlah volume yang besar.

6. Besar carrying cost tergantung secara garis lurus dengan rata-rata jumlah persediaan.

7. Besar ordering cost atau set up cost tetap untuk setiap lot yang dipesan dan tidak tergantung pada jumlah item pada setiap lot. 


\section{METODE PENELITIAN}

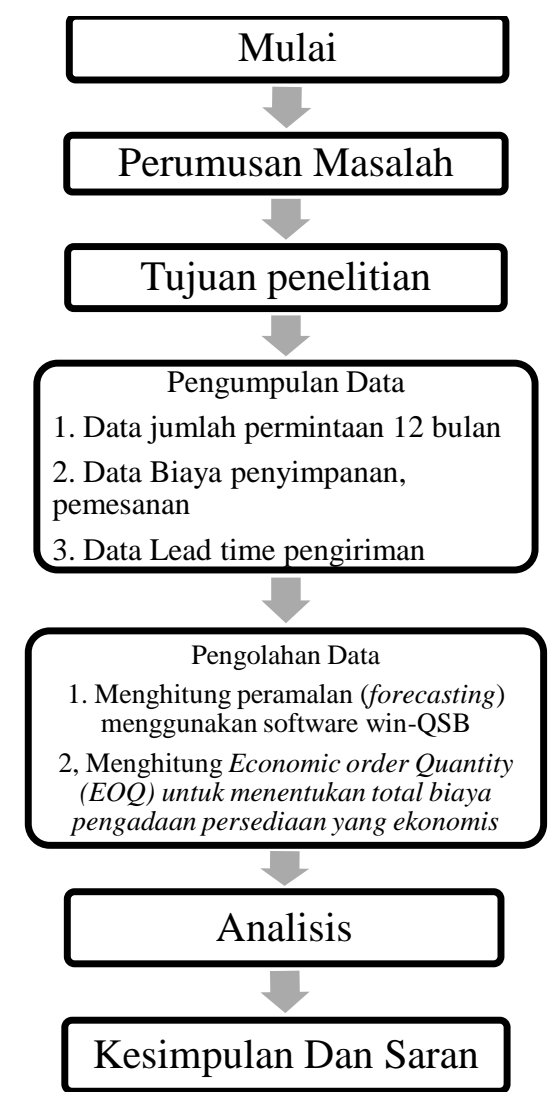

Gambar 1. Metodologi Penelitian

\section{HASIL DAN PEMBAHASAN}

Tabel 1. Data Permintaan Produk Oil Filter

\begin{tabular}{|c|c|c|c|c|c|c|c|c|c|c|c|c|c|c|c|}
\hline NO & PC & PART_NO & DESCRIPTION & NOV & DEC & JAN & FEB & MAR & APR & MAY JUN & JUL & AUG & SEPT & OKT \\
\hline 1 & VO & 21707134 & OILFILTER & 600 & 624 & 462 & 425 & 621 & 427 & 461 & 475 & 548 & 456 & 490 & 454 \\
\hline 2 & V0 & 21707132 & OIL FILTER & 456 & 520 & 360 & 355 & 410 & 334 & 312 & 320 & 426 & 384 & 390 & 360 \\
\hline 3 & VO & 21707133 & OIL FILTER & 403 & 308 & 459 & 313 & 273 & 370 & 277 & 271 & 465 & 367 & 305 & 290 \\
\hline
\end{tabular}

\section{A. Perhitungan PN VO 21707134}

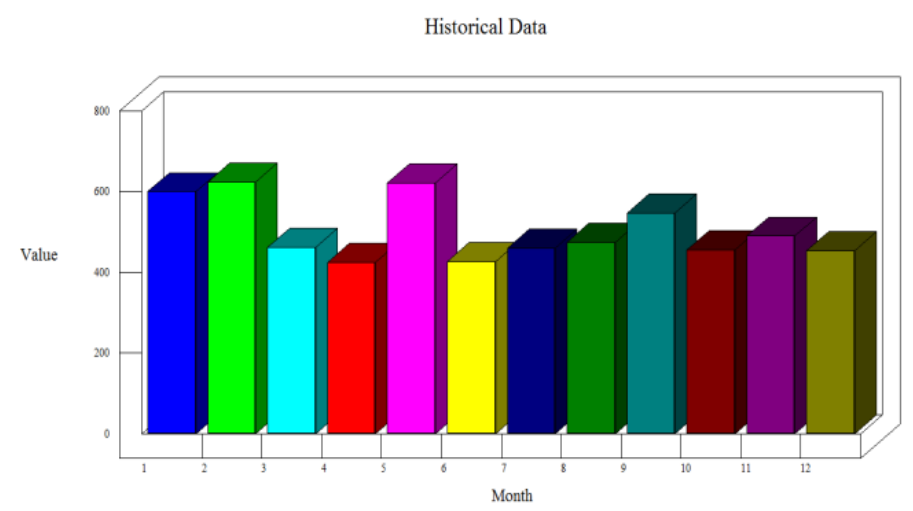

Gambar 2. Grafik Data Permintaan Produk Oil Filter part no 21707134 


\section{Perbandingan hasil pengukuran nilai error dari 4 metode}

Tabel 2.Perhitungan fitting eror

\begin{tabular}{|c|c|c|c|c|}
\hline \multirow{2}{*}{ No } & \multirow{2}{*}{ METODE } & \multicolumn{3}{|c|}{ ERROR } \\
\hline & & MAD & MSE & MAPE \\
\hline 1 & Linier Regresion & 54,12355 & 4054,217 & 10,7365 \\
\hline 2 & Moving Average & 81,45454 & 11076,18 & 16,66362 \\
\hline \multirow[t]{4}{*}{3} & $\begin{array}{l}\text { Single Exponential } \\
\text { Smoothing }\end{array}$ & & & \\
\hline & Alpha 0,1 & 83,60068 & 9438,899 & 18,19703 \\
\hline & Alpha 0,5 & 67,78409 & 7355,371 & 14,03031 \\
\hline & Alpha 0,9 & 77,49554 & 10074,31 & 15,83017 \\
\hline \multirow[t]{4}{*}{4} & $\begin{array}{l}\text { Holt Winter } \\
\text { Additive } \\
\text { Algorithm }\end{array}$ & & & \\
\hline & Alpha 0,1 & 83,60068 & 9438,899 & 18,19703 \\
\hline & Alpha 0,5 & 67,78409 & 7355,371 & 14,03031 \\
\hline & Alpha 0,9 & 77,49554 & 10074,31 & 15,83017 \\
\hline
\end{tabular}

Tabel 3.Verifikasi Peramalan Peta Rentang Bergerak

\begin{tabular}{|c|c|c|c|c|c|c|}
\hline PERIODE & $\mathrm{D}^{\prime}$ & $\mathrm{D}$ & $\mathrm{D}^{\prime}-\mathrm{D}$ & $\mathrm{UCL}$ & $\mathrm{LCL}$ & {$[\mathrm{MR}]$} \\
\hline 1 & 554 & 600 & -46 & 217,6364 & $-217,636$ & \\
\hline 2 & 545 & 624 & -79 & 217,6364 & $-217,636$ & 33 \\
\hline 3 & 535 & 462 & 73 & 217,6364 & $-217,636$ & 152 \\
\hline 4 & 526 & 425 & 101 & 217,6364 & $-217,636$ & 28 \\
\hline 5 & 518 & 621 & -103 & 217,6364 & $-217,636$ & 204 \\
\hline 6 & 508 & 427 & 81 & 217,6364 & $-217,636$ & 184 \\
\hline 7 & 499 & 461 & 38 & 217,6364 & $-217,636$ & 43 \\
\hline 8 & 499 & 475 & 24 & 217,6364 & $-217,636$ & 14 \\
\hline 9 & 481 & 548 & -67 & 217,6364 & $-217,636$ & 91 \\
\hline 10 & 471 & 456 & 15 & 217,6364 & $-217,636$ & 82 \\
\hline 11 & 462 & 490 & -28 & 217,6364 & $-217,636$ & 43 \\
\hline 12 & 452 & 454 & -2 & 217,6364 & $-217,636$ & 26 \\
\hline Total & \multicolumn{7}{|l}{} & 900 \\
\hline Rata - rata & \multicolumn{7}{|l}{} \\
\hline
\end{tabular}

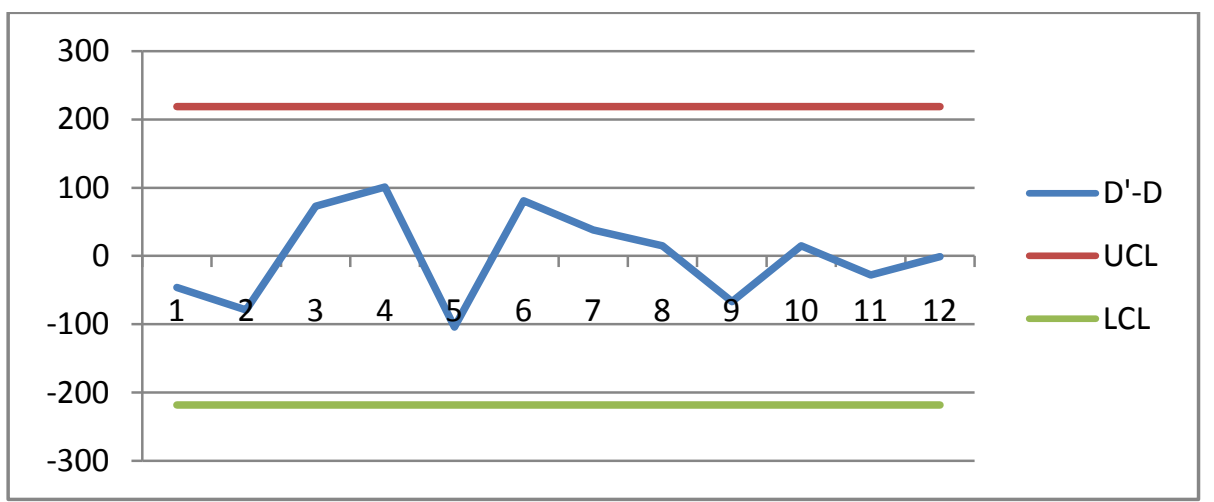

Gambar 3.Peta Rentang Bergerak 


\section{B. Perhitungan PN VO 21707132}

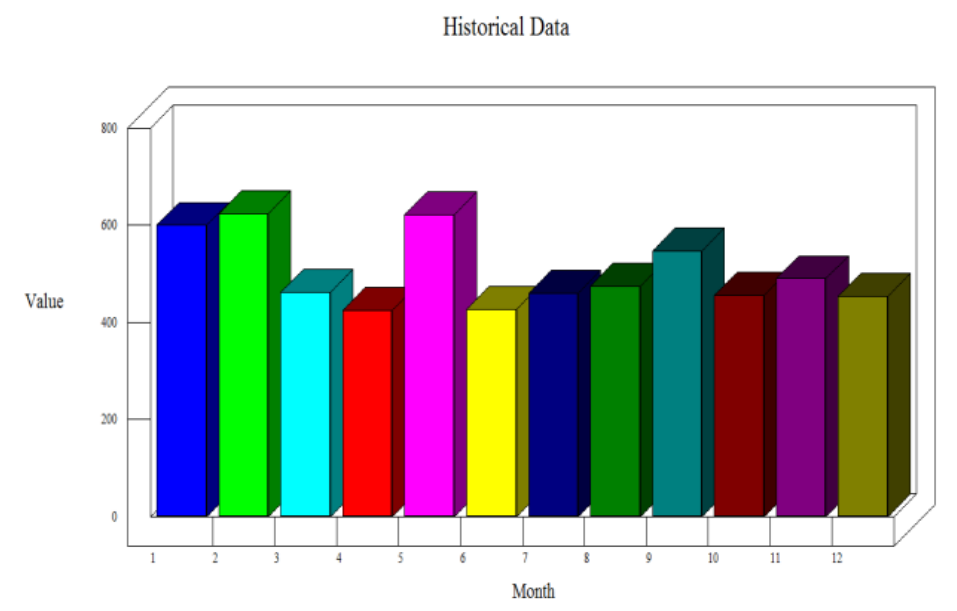

Gambar 4. Grafik Data Permintaan Produk Oil Filter part no 21707132

\section{Perbandingan hasil pengukuran error dari masing masing metode}

Tabel 4.Perhitungan fitting eror

\begin{tabular}{|c|c|c|c|c|}
\hline \multirow{2}{*}{ No } & \multirow{2}{*}{ METODE } & \multicolumn{3}{|c|}{ ERROR } \\
\cline { 3 - 5 } & & MAD & MSE & MAPE \\
\hline 1 & Linear Regresion & 46,38443 & 2745,069 & 12,1749 \\
\hline 2 & Moving Average & 52,18182 & 4818,727 & 13,59754 \\
\hline \multirow{2}{*}{3} & $\begin{array}{c}\text { Single Exponential } \\
\text { Smoothing }\end{array}$ & \multicolumn{3}{|c|}{} \\
\hline \multirow{4}{*}{4} & Alpha 0,1 & 65,49279 & 5677,48 & 18,4509 \\
\cline { 2 - 5 } & Alpha 0,5 & 50,7745 & 3956,537 & 13,56795 \\
\cline { 2 - 5 } & Alpha 0,9 & 51,47527 & 4545,162 & 13,44179 \\
\hline \multirow{2}{*}{4} & Holt Winter Additive & \multicolumn{3}{|c}{} \\
\hline & Algorithm & & & \\
& Alpha 0,1 & 65,49279 & 5677,48 & 18,4509 \\
\cline { 2 - 5 } & Alpha 0,5 & 50,7745 & 3956,537 & 13,56795 \\
\cline { 2 - 5 } & Alpha 0,9 & 51,47527 & 4545,162 & 13,44179 \\
\hline
\end{tabular}


Tabel 5.Verifikasi Peramalan Peta Rentang Bergerak

\begin{tabular}{|c|c|c|c|c|c|c|}
\hline PERIODE & $\mathrm{D}^{\prime}$ & $\mathrm{D}$ & $\mathrm{D}^{\prime}-\mathrm{D}$ & $\mathrm{UCL}$ & $\mathrm{LCL}$ & {$[\mathrm{MR}]$} \\
\hline 1 & 424 & 456 & -32 & 138,0782 & $-138,078$ & \\
\hline 2 & 417 & 520 & -103 & 138,0782 & $-138,078$ & 71 \\
\hline 3 & 410 & 360 & 50 & 138,0782 & $-138,078$ & 153 \\
\hline 4 & 403 & 355 & 48 & 138,0782 & $-138,078$ & 2 \\
\hline 5 & 396 & 410 & -14 & 138,0782 & $-138,078$ & 62 \\
\hline 6 & 389 & 334 & 55 & 138,0782 & $-138,078$ & 69 \\
\hline 7 & 382 & 312 & 70 & 138,0782 & $-138,078$ & 15 \\
\hline 8 & 375 & 320 & 55 & 138,0782 & $-138,078$ & 15 \\
\hline 9 & 368 & 426 & -58 & 138,0782 & $-138,078$ & 113 \\
\hline 10 & 361 & 384 & -23 & 138,0782 & $-138,078$ & 35 \\
\hline 11 & 354 & 390 & -36 & 138,0782 & $-138,078$ & 13 \\
\hline 12 & 347 & 360 & -13 & 138,0782 & $-138,078$ & 23 \\
\hline Total & \multicolumn{7}{|l}{} & 571 \\
\hline Rata - rata & \multicolumn{7}{|l|}{} \\
\hline
\end{tabular}

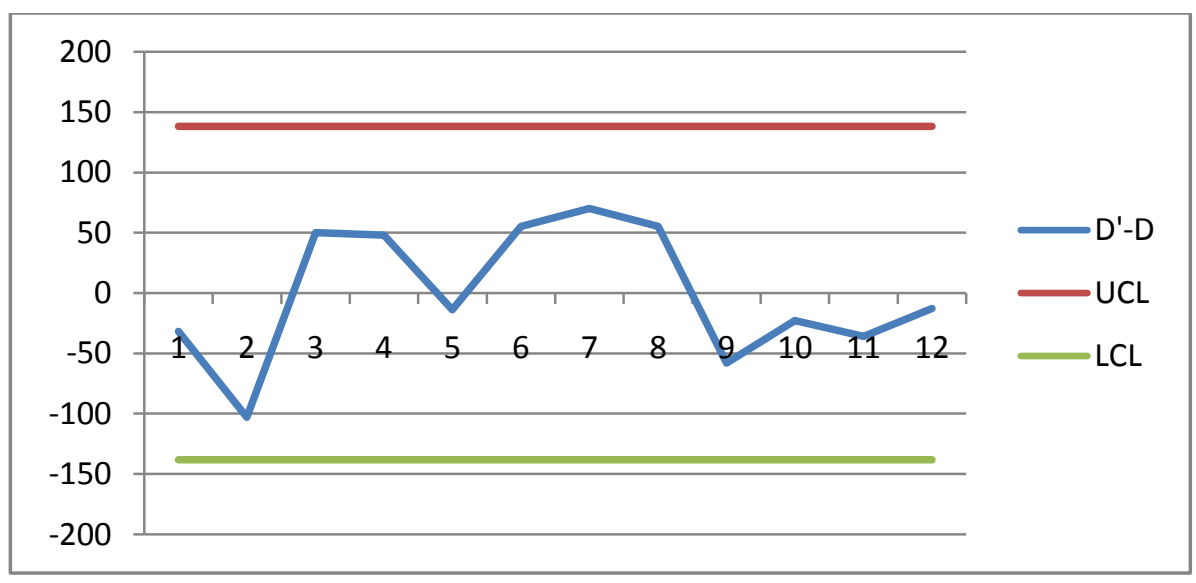

Gambar 5.Peta Rentang Bergerak

\section{Perhitungan PN VO 21707133}

Historical Data

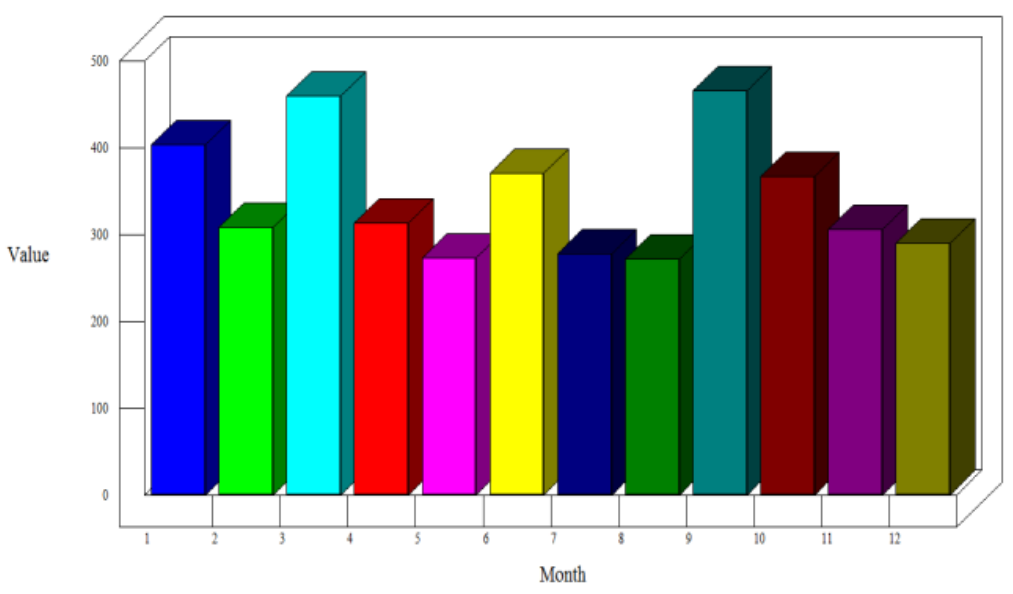

Gambar 6. Grafik Data Permintaan Produk Oil Filter part no 21707133 
Perbandingan hasil pengukuran error dari masing masing metode

Tabel 6.Perhitungan fitting eror

\begin{tabular}{|c|c|c|c|c|}
\hline \multirow{2}{*}{ No } & \multirow{2}{*}{ METODE } & \multicolumn{3}{|c|}{ ERROR } \\
\hline & & MAD & MSE & MAPE \\
\hline 1 & Linear Regresion & 56,65268 & 4274,957 & 16,45057 \\
\hline 2 & Moving Average & 90,63636 & 11285,91 & 25,54236 \\
\hline \multirow[t]{4}{*}{3} & $\begin{array}{c}\text { Single Exponential } \\
\text { Smoothing }\end{array}$ & & & \\
\hline & Alpha 0,1 & 74,52088 & 6862,513 & 23,72793 \\
\hline & Alpha 0,5 & 76,3671 & 7495,178 & 22,50646 \\
\hline & Alpha 0,9 & 88,59989 & 10322,45 & 25,18068 \\
\hline \multirow[t]{4}{*}{4} & $\begin{array}{c}\text { Holt Winter } \\
\text { Additive Algorithm }\end{array}$ & & & \\
\hline & Alpha 0,1 & 74,52088 & 6862,513 & 23,72793 \\
\hline & Alpha 0,5 & 76,3671 & 7495,178 & 22,50646 \\
\hline & Alpha 0,9 & 88,59989 & 10322,45 & 25,18068 \\
\hline
\end{tabular}

Tabel 7.Verifikasi Peramalan Peta Rentang Bergerak

\begin{tabular}{|c|c|c|c|c|c|c|}
\hline PERIODE & $\mathrm{D}^{\prime}$ & $\mathrm{D}$ & $\mathrm{D}^{\prime}-\mathrm{D}$ & $\mathrm{UCL}$ & $\mathrm{LCL}$ & {$[\mathrm{MR}]$} \\
\hline 1 & 366 & 403 & -37 & 256,956 & $-256,956$ & \\
\hline 2 & 361 & 308 & 53 & 256,956 & $-256,956$ & 90 \\
\hline 3 & 357 & 459 & -102 & 256,956 & $-256,956$ & 155 \\
\hline 4 & 353 & 313 & 40 & 256,956 & $-256,956$ & 142 \\
\hline 5 & 348 & 273 & 75 & 256,956 & $-256,956$ & 35 \\
\hline 6 & 344 & 370 & -26 & 256,956 & $-256,956$ & 101 \\
\hline 7 & 340 & 277 & 63 & 256,956 & $-256,956$ & 89 \\
\hline 8 & 335 & 271 & 64 & 256,956 & $-256,956$ & 1 \\
\hline 9 & 331 & 465 & -134 & 256,956 & $-256,956$ & 198 \\
\hline 10 & 327 & 367 & -40 & 256,956 & $-256,956$ & 94 \\
\hline 11 & 322 & 305 & 17 & 256,956 & $-256,956$ & 57 \\
\hline 12 & 318 & 290 & 28 & 256,956 & $-256,956$ & 11 \\
\hline Total & \multicolumn{7}{|l}{} & 973 \\
\hline Rata - rata & \multicolumn{7}{|l|}{} \\
\hline
\end{tabular}




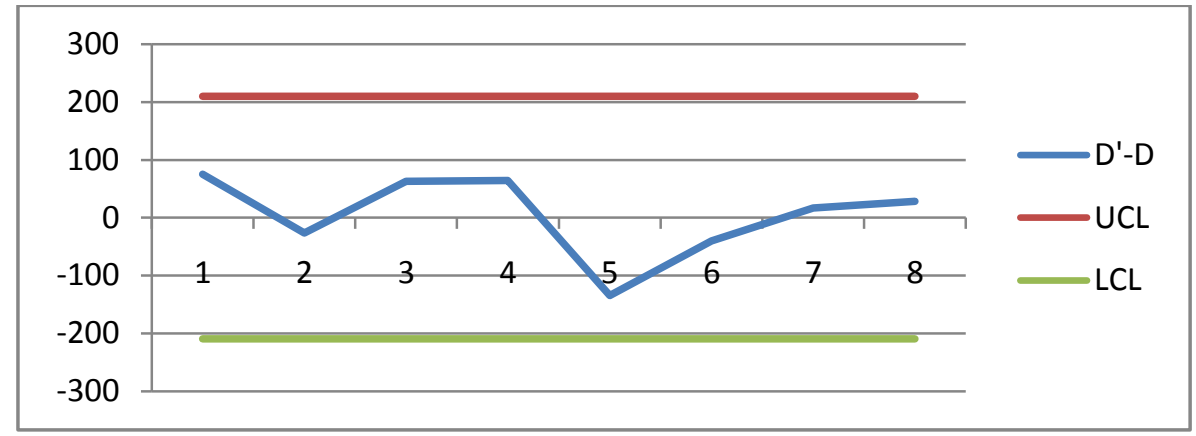

Gambar 7.Peta Rentang Bergerak

Tabel 8.Perbandingan hasil peramalan 3 part

\begin{tabular}{|c|c|c|c|}
\hline \multirow{2}{*}{ Periode } & \multicolumn{3}{|c|}{ No Part } \\
\cline { 2 - 4 } & 21707134 & 21707132 & 21707133 \\
\hline 13 & 444 & 340 & 313 \\
\hline 14 & 434 & 333 & 309 \\
\hline 15 & 425 & 326 & 305 \\
\hline 16 & 416 & 319 & 300 \\
\hline 17 & 407 & 312 & 296 \\
\hline 18 & 397 & 305 & 292 \\
19 & 388 & 298 & 287 \\
20 & 379 & 291 & 283 \\
21 & 370 & 284 & 278 \\
22 & 360 & 277 & 274 \\
23 & 351 & 270 & 269 \\
24 & 342 & 264 & 265 \\
\hline
\end{tabular}

Berdasarkan dari data hasil peramalan yang sudah dihitung dengan software QSB, maka penentuan jumlah pembelian yang ekonomis didasarkan pada pertimbangan efisiensi biaya pembelian.Oleh karena itu perlu dirumuskan mengenai model peritungan biaya pembelian berdasarkan dari komponen biaya pada data yang sudah ada.dari plan yang didapatkan diatas metode usulan yang didapatkan melalui perhitungan metode EOQ untuk mendapatkan total cost yang optimal.

\section{Perhitungan EOQ oli filter part 21707134}

Perhitungan $\mathrm{D}=$ Total kebutuhan bersih $/ \mathrm{n}=4713 / 12=392,75 \approx 393$

Perhitungan EOQ $\quad=\sqrt{2 . D \cdot S / H}$

$$
=\sqrt{2.393 .1400 / 2}=742
$$


Tabel 9. Perhitungan EOQ oli filter part 21707134

\begin{tabular}{|l|c|c|c|c|c|c|c|c|c|c|c|c|c|}
\hline \multicolumn{1}{|c|}{ Periode } & Des & Jan & Feb & Mar & Apr & Mei & Jun & Jul & Agust & Sep & Okt & Nop & Des \\
\hline $\begin{array}{l}\text { Kebutuhan } \\
\text { kotor }\end{array}$ & & 444 & 434 & 425 & 416 & 407 & 397 & 388 & 379 & 370 & 360 & 351 & 342 \\
\hline Persediaan & & 250 & & & & & & & & & & & \\
\hline $\begin{array}{l}\text { Kebutuhan } \\
\text { bersih }\end{array}$ & 194 & 434 & 425 & 416 & 407 & 397 & 388 & 379 & 370 & 360 & 351 & 342 \\
\hline $\begin{array}{l}\text { Rencana } \\
\text { penerimaan }\end{array}$ & & 742 & 0 & 742 & 0 & 742 & 742 & 0 & 742 & 0 & 742 & 0 & 742 \\
\hline $\begin{array}{l}\text { Persediaan } \\
\text { akhir }\end{array}$ & 548 & 114 & 431 & 15 & 350 & 695 & 307 & 670 & 300 & 682 & 331 & 731 \\
\hline $\begin{array}{l}\text { Recana } \\
\text { pemesanan }\end{array}$ & 742 & 0 & 742 & 0 & 742 & 742 & 0 & 742 & 0 & 742 & 0 & 742 & 0 \\
\hline
\end{tabular}

Total biaya pesan

Total biaya penyimpanan

Total Biaya

$$
\begin{aligned}
& =\text { Biaya pesan } \times \text { total pemesanan } \\
& =\$ 1.400 \times 7=\$ 9.800 \\
& =\text { Biaya simpan } \times \text { total persediaan akhir } \\
& =\$ 2,00 \times 5174=\$ 10.348 \\
& =\text { Total Biaya pesan }+ \text { Total biaya simpan } \\
& =\$ 9.800+\$ 10.348=\$ 20.148
\end{aligned}
$$

\section{Perhitungan EOQ oli filter part 21707132}

Perhitungan $\mathrm{D}=$ Total kebutuhan bersih/n

$$
=3619 / 12=301,5 \approx 302
$$

$$
\begin{array}{ll}
\text { Perhitunga EOQ } & =\sqrt{2 \cdot D \cdot S / H} \\
& =\sqrt{2 \cdot 302 \cdot 1400 / 2} \\
& =650
\end{array}
$$

Tabel 10. Perhitungan EOQ oli filter part 21707132

\begin{tabular}{|l|c|c|c|c|c|c|c|c|c|c|c|c|c|}
\hline \multicolumn{1}{|c|}{ Periode } & Des & Jan & Feb & Mar & Apr & Mei & Jun & Jul & Agust & Sep & Okt & Nop & Des \\
\hline $\begin{array}{l}\text { Kebutuhan } \\
\text { kotor }\end{array}$ & & 340 & 333 & 326 & 319 & 312 & 305 & 298 & 291 & 284 & 277 & 270 & 264 \\
\hline Persediaan & & 200 & & & & & & & & & & & \\
\hline $\begin{array}{l}\text { Kebutuhan } \\
\text { bersih }\end{array}$ & & 140 & 333 & 326 & 319 & 312 & 305 & 298 & 291 & 284 & 277 & 270 & 264 \\
\hline $\begin{array}{l}\text { Rencana } \\
\text { penerimaan }\end{array}$ & & 650 & 0 & 650 & 0 & 650 & 0 & 650 & 0 & 650 & 0 & 0 & 650 \\
\hline $\begin{array}{l}\text { Persediaan } \\
\text { akhir }\end{array}$ & 510 & 177 & 501 & 182 & 520 & 215 & 567 & 276 & 642 & 365 & 95 & 481 \\
\hline $\begin{array}{l}\text { Recana } \\
\text { pemesanan }\end{array}$ & 650 & 0 & 650 & 0 & 650 & 0 & 650 & 0 & 650 & 0 & 0 & 650 & 0 \\
\hline
\end{tabular}

Total biaya pesan

Total biaya penyimpanan

Total Biaya
$=$ Biaya pesan $\mathrm{x}$ total pemesanan

$=\$ 1.400 \times 6=\$ 8.400$

= Biaya simpan $\mathrm{x}$ total persediaan akhir

$=\$ 2,00 \times 4.531=\$ 9.062$

$=$ Total Biaya pesan + Total biaya simpan

$=\$ 8.400+\$ 9.062=\$ 17.462$ 


\section{Perhitungan EOQ oli filter part 21707133}

$$
\begin{aligned}
& \text { Perhitungan } \mathrm{D}=\text { Total kebutuhan bersih } / \mathrm{n} \\
& =3471 / 12=289,25 \approx 290 \\
& \text { Perhitunga EOQ } \quad=\sqrt{2 . D \cdot S / H} \\
& =\sqrt{2.290 .1400 / 2}=637
\end{aligned}
$$

Tabel 11. Perhitungan EOQ oli filter part 21707133

\begin{tabular}{|l|c|c|c|c|c|c|c|c|c|c|c|c|c|}
\hline \multicolumn{1}{|c|}{ Periode } & Des & Jan & Feb & Mar & Apr & Mei & Jun & Jul & Agust & Sep & Okt & Nop & Des \\
\hline $\begin{array}{l}\text { Kebutuhan } \\
\text { kotor }\end{array}$ & & 313 & 309 & 305 & 300 & 296 & 292 & 287 & 283 & 278 & 274 & 269 & 265 \\
\hline Persediaan & 150 & & & & & & & & & & & \\
\hline $\begin{array}{l}\text { Kebutuhan } \\
\text { bersih }\end{array}$ & 163 & 309 & 305 & 300 & 296 & 292 & 287 & 283 & 278 & 274 & 269 & 265 \\
\hline $\begin{array}{l}\text { Rencana } \\
\text { penerimaan }\end{array}$ & 637 & 0 & 637 & 0 & 637 & 0 & 637 & 0 & 0 & 637 & 0 & 637 \\
\hline $\begin{array}{l}\text { Persediaan } \\
\text { akhir }\end{array}$ & 474 & 165 & 497 & 197 & 538 & 246 & 596 & 313 & 35 & 398 & 129 & 501 \\
\hline $\begin{array}{l}\text { Recana } \\
\text { pemesanan }\end{array}$ & 637 & 0 & 637 & 0 & 637 & 0 & 637 & 0 & 0 & 637 & 0 & 637 & 0 \\
\hline
\end{tabular}

Total biaya pesan

= Biaya pesan $\mathrm{x}$ total pemesanan

$=\$ 1.400 \times 6=\$ 8.400$

Total biaya penyimpanan

$=$ Biaya simpan $\mathrm{x}$ total persediaan akhir

$=\$ 2,00 \times 4.089=\$ 8.178$

Total Biaya

$$
\begin{aligned}
& =\text { Total Biaya pesan }+ \text { Total biaya simpan } \\
& =\$ 8.400+\$ 8.178=\$ 16.578
\end{aligned}
$$

Tabel 12. Hasil Perbandingan Metode EOQ

\begin{tabular}{|c|c|c|c|c|c|c|c|c|c|c|c|c|c|c|c|c|c|c|}
\hline No & $P C$ & PARTNO & Description & Nov & Des & $\operatorname{Jan} \mid F$ & Feb 1 & Mrt $A$ & \begin{tabular}{l|l} 
Apr & $M$
\end{tabular} & Mei|Jun & uni|Juli & $\mid$ Agst $\mid$ & Sept & Okt & \begin{tabular}{|c|} 
TOTAL \\
DEMAND
\end{tabular} & $\begin{array}{c}\text { Biaya } \\
\text { Pemesanan }\end{array}$ & $\begin{array}{c}\text { Biaya } \\
\text { Penyimpanan }\end{array}$ & $\begin{array}{l}\text { Total } \\
\text { Cost }\end{array}$ \\
\hline 1 & vo & 21707134 & OIL FILTER & 452 & 452 & 452 & 452 & 452 & \begin{tabular}{l|l}
452 & 4 \\
\end{tabular} & \begin{tabular}{l|l}
452 & 45 \\
\end{tabular} & \begin{tabular}{l|l|}
52 & 452 \\
\end{tabular} & 452 & 452 & 452 & 5.424 & 16.800 & 6.000 & 22.800 \\
\hline 2 & vo & 21707132 & OIL FILTER & 318 & 318 & 318 & 318 & 3183 & \begin{tabular}{l|l}
318 & 3 \\
\end{tabular} & \begin{tabular}{l|l|}
318 & 31 \\
\end{tabular} & \begin{tabular}{l|l|}
118 & 318 \\
\end{tabular} & 318 & 318 & 318 & 3.816 & 16.800 & 3.600 & 20.400 \\
\hline 3 & vo & 21707133 & OIL FILTER & 321 & 3213 & $321=$ & 321 & 3213 & \begin{tabular}{l|l}
321 & 3 \\
\end{tabular} & \begin{tabular}{l|l}
321 & 32
\end{tabular} & \begin{tabular}{|l|l|}
221 & 321 \\
\end{tabular} & 321 & 321 & 321 & 3.852 & 16.800 & 4.800 & 21.600 \\
\hline & & & & & & & & & & TOTA & & & & & & & & 64.800 \\
\hline
\end{tabular}

\begin{tabular}{|c|c|cr|}
\hline NO & \multirow{2}{*}{ Jenis Part } & \multicolumn{2}{|c|}{ MetodeEOQ } \\
\cline { 1 - 1 } 1 & 21707134 & $\$$ & 20.148 \\
\hline 2 & 21707132 & $\$$ & 17.462 \\
\hline 3 & 21707133 & $\$$ & 16.578 \\
& TOTAL & $\$$ & 54.188 \\
\hline
\end{tabular}

\section{Data Rencana Pembeliaan Perusahaan}

Data rencana pembeliaan ini disusun oleh team inventory perusahaan berdasarkan target ketersediaan yang disyaratkan oleh management.berikut data rencana pembeliaan perusahaan:

Tabel 13.Data Rencana Pembelian Perusahaan November 2014-April 2015

(Sumber Data : PT Indotruk Utama) 
Tabel 14. Hasil Perbandingan Perhitungan Metode Perusahaan dengan Metode EOQ

\begin{tabular}{|c|c|c|c|c|}
\hline $\mathrm{NO}$ & $\begin{array}{l}\text { PART } \\
\text { NUMBER }\end{array}$ & DESCRIPTION & $\begin{array}{l}\text { PERHITUNGAN } \\
\text { PERUSAHAAN }\end{array}$ & $\begin{array}{l}\text { METODE } \\
\text { EOQ }\end{array}$ \\
\hline 1 & 21707134 & OIL FILTER & $\$ 22.800$ & $\begin{array}{c}\$ \\
20.148\end{array}$ \\
\hline 2 & 21707132 & OIL FILTER & $\$ 20.400$ & $\begin{array}{c}\$ \\
17.462\end{array}$ \\
\hline 3 & 21707133 & OIL FILTER & $\$ 21.600$ & $\begin{array}{c}\$ \\
16.578 \\
\end{array}$ \\
\hline \multicolumn{3}{|c|}{ TOTAL } & $\$ 64.800$ & $\$ 54.188$ \\
\hline
\end{tabular}

(Sumber Data : Hasil Perhitungan)

Dari hasil perhitungan perbandingan diatas didapatkan nilai metode EOQ lebih kecil dari pada total rencana pembelian perusahaan untuk ketiga oil filter ini. dimana total rencana pembelian perusahaan lebih besar yaitu sebesar $\$ 64.800$ bila dibandingkan dengan metode EOQ sebesar \$ 54.188 ada selisih sebesar $\$ 10.612$

\section{KESIMPULAN DAN SARAN}

\section{Kesimpulan}

1. Hasil forecasting jumlah pembelian parts oil filter untuk 1 tahun kedepan yaitu :

\begin{tabular}{|c|c|c|c|}
\hline \multirow{2}{*}{ Periode } & \multicolumn{3}{|c|}{ No Part Oil Filter } \\
\cline { 2 - 4 } & 21707134 & 21707132 & 21707133 \\
\hline 1 & 444 & 340 & 313 \\
\hline 2 & 434 & 333 & 309 \\
\hline 3 & 425 & 326 & 305 \\
\hline 4 & 416 & 319 & 300 \\
\hline 5 & 407 & 312 & 296 \\
\hline 6 & 397 & 305 & 292 \\
\hline 7 & 388 & 298 & 287 \\
\hline 8 & 379 & 291 & 283 \\
\hline 9 & 370 & 284 & 278 \\
\hline 10 & 360 & 277 & 274 \\
\hline 11 & 351 & 270 & 269 \\
\hline 12 & 342 & 264 & 265 \\
\hline
\end{tabular}

2. Berdasarkan analisis perhitungan didapatkan hasil biaya paling ekonomis dalam melakukan pemesanan suku cadang oil filter menggunakan metode economic order quantity (EOQ) didapatkan total biaya $\$ 54.188$, Hasil perhitungan metode EOQ ini lebih kecil daripada total rencana pembelian perusahaan untuk ketiga oil filter ini dimana total rencana pembelian perusahaan lebih besar yaitu sebesar $\$ 64.800$ dan ada selisih sebesar $\$ 10.612$ dengan demikian tentunya metode EOQ bisa menjadi pilihan perusahaan sebagai metode untuk melakukan proses order yang paling ekonomis serta diharapkan mampu menghilangkan pemborosan yang terjadi dalam biaya pengadaan suku cadang dan sesuai dengan kebijakan manajemen PT Indotruck utama yang mengharuskan adanya persediaan akhir. 


\section{Saran}

1. Diperlukan komitmen, ketelitian dan monitoring dari semua PIC atau karyawan yang terkait dalam proses order suku cadang ini agar bisa memenuhi permintaan kebutuhan suku cadang, data yang akurat dan lead time yang tepat.

2. Dalam melakukan forecasting tidak hanya berdasarkan data historical permintaan sebelumnya tetapi juga harus ditambahkan dengan data dan rekomendasi dari team service dan marketing dalam menentukan jumlah stock order.

\section{DAFTAR PUSTAKA}

1. Arman Hakim Nasution dan Yudha Prasetyawan, 2008, Perencanaan Dan Pengendalian Produksi, Yogyakarta, Graha Ilmu.

2. Diana Khairani Sofyan, ST.MT, 2013, "Perencanaan dan Pengendalian Produksi", Graha Ilmu.

3. Eddy Herjanto, 1999, Manajemen Produksidan Operasi, Grasindo.

4. John E Biegel, 2009, Pengendalian Produksi, Cetakan Kedua CV Akademika Presindo.

5. Rosnani Ginting, 2007, "Sistem produksi", Graha Ilmu.

6. Vincent Gaspersz, 2009, Production Planning and Inventory Control, berdasarkan pendekatan sistem terintegrasi MRP II dan JIT Menuju Manufacturing 21, Jakarta, PT Gramedia Pustaka Utama. 
